\title{
THE RIGHT TO WATER AND THE RIGHT TO USE HYDROPOWER: THE CASE OF SERBIA AND LESSONS LEARNED FROM THE EU
}

\author{
Mirjana Drenovak Ivanović, PhD, Associate Professor \\ University of Belgrade, Faculty of Law \\ Bulevar kralja Aleksandra 67, Belgrade, Serbia \\ mirjana.drenovak@ius.bg.ac.rs
}

\begin{abstract}
Water is a resource with the capacity to generate power in many forms whether be it access to drinking water or use as hydropower or steam power to produce electricity. Renewable recourses open issues where environmental protection meets different requirements: to protect the quality and national potential of water, but to develop the use of emission-free hydropower; to strengthen constitutional and legal guaranties to access to water but to provide adequate type of rights to use hydropower. The right to use water for hydropower must be weighed with its impact on the quality and quantity of water courses. In comparative law we may find different approaches that should guarantee the right to water. The concept that the right to water might be protected only if water is recognized as a legal person (exercised in recent cases the Amazon River, Ganges and Yamuna rivers, Whanganui river) will be challenged with EU approach where measurement on different interests of environmental protection is the base for water protection. The article outline elements that provide minimum guarantees for including the both rights in decision-making process singled out in practice of jurisprudence of the Court of Justice of the European Union. The article points out the most important case under the Serbian Administrative Court on small hydropower licensing in 2018. The aim of the article is to examine if the conclusions from EU may be find in Serbian law and to suggest legal changes that could lead to full transposition of environmental acquis.
\end{abstract}

Keywords: Human Right to Water. - Small hydropower plant. - European Commission v. Republic of Austria, C-346/14. - C-664/15 Protect Natur-. - Rights of the Amazon River. - Whanganui River Claims Settlement. -Ganges and Yamuna Rivers as a Legal Person. Serbian General Administrative Procedure Act

\section{INTRODUCTION}

The right to water evolved from the right to health, established in 1946 with the founding of the World Health Organization, and further mentioned in the Universal Declaration of Human Rights of 1948 and the International Convention on Economic, Social and Cultural Rights of 1966. An explicit protection of the right to water was introduced as late as in 1979, in the Convention on the Elimination of All Forms of Discrimination against Women and in Article 24 of the 
Convention on the Rights of the Child of 1989. Prohibition of the denial of food and water to prisoners of war is mentioned in the Protocols to the Geneva Conventions of 1977, relating to the implementation of international humanitarian law in armed conflicts. ${ }^{1}$ The Protocol on Water and Health to the 1999 Convention on the Protection and Use of Transboundary Watercourses and International Lakes obliges Parties to provide access to drinking water and sanitation. ${ }^{2}$ The idea that "it is vital to recognize first the basic rights of all human beings to have access to clean water" was supported by the UN Resolution where "the right to food and clean water are fundamental human rights". ${ }^{3}$ In 2010, the human right to water is recognized as essential to the realization of all human rights. ${ }^{4}$

There are several ways of treating the right to water: as a human right, as a constitutionally guaranteed right out of basic human rights and as a law whose speciality is guaranteed through the protection of public interest in accordance with legal traditions of a certain country. ${ }^{5}$ The question then arises whether within the existing framework of legal protection there is a possibility of identifying an interest in protecting the quality and quantity of water that would have a dominating influence in determining the public interest. The development of environmental law indicates that the need to protect the environment requires a more frequent involvement of various public interests, each of them aiming to protect the environment. One of examples causing diametric positions and controversy in recent years is the construction of small hydropower plants that both stimulates the development of use of energy from renewable sources and causes encroachment on the environment much less than when other sources for obtaining power generation are used. Ideally, the impact on the quality and quantity of water should be minimal. However, in practice, the right to water and the right to small hydropower plants often fail to create a balance aiming at protection and preservation of the environment, but present competing public interests instead.

The first dilemma arises at an attempt to define a small hydropower plant, knowing that the international law does not recognise a unified position on the capac-

1 McCaffrey, S.C., A human right to water: Domestic and international implications, Geo. Int'l Envtl. L. Rev., Vol. 5, p. 1; Gleick, P.H., The human right to water, Water policy, Vol. 1, No. 5,1998, pp. 487-503

2 Convention on the Protection and Use of Transboundary Watercourses and International Lakes, Helsinki, 17 March 1992, Art. 6(1) [https://www.unece.org/env/water/] 31.03.2019

3 Compare: International Conference on Water and Sustainable Development, 1992, Principle 4 and UN General Assembly Resolution A/Res/54/175 The Right to Development, 1992, Art. 12

4 Resolution adopted by the General Assembley on 28 July 2010, no. 64/292, The human right to water and sanitation, [https://www.un.org/en/ga/search/view_doc.asp?symbol=A/RES/64/292] 06.04.2019

5 Daly, E., Environmental Constitutionalism in Defense of Nature, Wake Forest L. Rev., Vol. 53, 2018, p. 667 
ity of small hydropower plants. Thus, in China, this term covers the hydropower plants with capacity up to $25 \mathrm{MWh}$, in India up to $10 \mathrm{MWh}$, and in Sweden to up to $1.5 \mathrm{MWh}$. According to the EU standard, a small hydropower plants are those of capacity lower than $10 \mathrm{MWh} .{ }^{6}$ In order to implement the Renewable Electricity Directive and to contribute to the EU energy targets for 2020-2030, hydropower plants have to conform to the requirements of the Water Framework Directive, the Floods Directive, the Birds and Habitats Directives and Environmental Assessments Directives. ${ }^{7}$

Following the introduction, the second part of the paper aims to determine whether there is a dominant model found among the EU Member States regarding the constitutional protection of the right to water and to provide an answer regarding the model used in Serbian law. The third part analyses the comparative models of protection, which raises a dilemma of whether legal protection should be based on the model of water as a legal person, which is found in the recent cases in Colombia, India and New Zealand, or the basis should be the legal framework which estimates various interests of environmental protection, such as balancing the interest of energy production from renewable sources and the interest of protecting and maintaining water quality and quantity. Further, in the fourth part, by analysing the CJEU practice we determine whether the public interest is equal to the interest of environmental protection. We also analyse the CJEU practice in order to discover criteria which determine the basis of the public interest, and how to weigh up the overriding interest in the situation when two different interests of environmental protection are engaged. The fifth part of the paper points to the existing practice of issuing permits for construction of small hydropower plants in Serbia and analyses a recent case in which the Supreme Court of Cassation overturned the decision on construction of a small hydropower plant. The concluding observations compare analysed models.

6 From arround 23.000 hydropower installations registered in EU, 91\% are small and generate 13\% of the total electricity production from hydropower. European Commission, Guidance on the requirements for hydro power in relation to Natura 2000, European Commission, 2018, p. 19

7 Among the Member States we encounter those who consider obtaining energy from renewable sources related to the climate change and the use of water and wind power as dominant. Thus, for example, in late 2018 Spain presented a draft Climate Change and Energy Transition law defining progressive closure plan for coal-fired power plants without new licenses for fossil fuel. The ending of use of coal by 2025 will lead to fullfilment of a goal of $100 \%$ renewable power sources for electricity by 2050. Spain plans switch to 100\% renewable electricity by 2050, [https://www.theguardian.com/environment/2018/ nov/13/spain-plans-switch-100-renewable-electricity-2050] Accessed 13.11.2018 


\section{THE RIGHT TO WATER AS A CONSTITUTIONALLY GUARANTEED RIGHT IN THE EU MEMBER STATES AND IN SERBIA}

The right to water must be considered through both natural and social dimension. The natural dimension of water indicates that it is a right that puts water into a special category per se, while the social dimension indicates the need to approach the protection of the right to water taking into account all the values of water in a certain society. ${ }^{8}$ Among the EU states we find several different approaches to the protection of the right to water. The first approach is found in those countries that treat the right to access to water as a basic human right (Belgium, Finland, France, Spain, Sweden, United Kingdom). ${ }^{9}$

The second approach is found in the Member States that do not regulate the right to water as a basic human right, but allow the possibility of special protection of the right to drinking water in an administrative procedure and dispute. ${ }^{10}$ An example is found in Germany, where the protection of access to water is not connected to the protection of individual rights but, starting from the traditional terms of the German legal tradition, it is related to the protection of the principle of public interest (Daseinsvorsorge) and the welfare state (Sozialstaatsprinzip). ${ }^{11}$ Such approach opens the possibility that the right to water is granted protection that is broader than the protection of a basic human right. ${ }^{12}$ In the first case, the legal protection includes planning, management, mechanisms for monitoring the control of drinking water, guarantees that water will be of a certain quality. In addition, by protecting water as a public interest the interests of an individual are also protected.

$8 \quad$ Lillo, A., Is Water Simply a Flow: Exploring an Alternative Mindset for Recognizing Water as a Legal Person, Vt. J. Envtl. L., Vol. 19, 2018, p. 164

9 Zobavnik, I., Pitna voda, Državni zbor, 2015, p. 24.

10 Constitution of Germany does not mention the term "environment". Article 20a, which deals with this issue, is titled "Protection of the natural foundations of life and animals". An "environmental duty" for individuals does not exist in the German constitutional system. Environmental protection in the Constitution of Germany is defined in such a manner that it does not grant an actionable right to the citizens. Grundgesetz für die Bundesrepublik Deutschland [Basic Law of the Federal Republic of Germany] art 20a. Rodi, M., Public environmental law in Germany, Comparative Environmental Law in Europe. An Introduction to Public Environmental Law in EU Member States, The Hague: Kluwer, 2002, pp. 199-245

11 Bullinger, M., Französischer service public und deutsche Daseinsvorsorge, Juristenzeitung, 2003, pp.597604. See: Clausen, S.; Kramer, D.R., Bericht über die 32. Fachtagung der Gesellschaft für Umweltrecht, Natur und Recht, Vol. 31, No. 2, 2009, pp. 104-107

12 Gordon, G.J., Environmental Personhood, Colum. J. Envtl. L., Vol. 43, 2018, p.49; Bluemel, E.B., The implications of formulating a human right to water, Ecology LQ, Vol. 31, 2004, p. 957 
The third approach is found in those Member States that constitutionally guarantee the right to access to water per se, not as a separate human right (Slovenia and Slovakia). The right to drinking water is guaranteed by the Constitution of Slovak Republic, but not as a basic human right. Slovak Constitution stipulates that groundwater and waterways are owned by the state, which, on behalf of citizens and future generations, is obliged to protect, take care and improve the quality of natural resources, including water. This Constitution prohibits any act of export of water from the country, including the possibility of export through water supply network. In November 2016, Slovenia became the first EU Member State that guarantees in its Constitution the right to access to drinking water. According to Art. 70a of Slovenian Constitution, everyone has the right to drinking water, and the water is a public resource managed by the state. The Constitution further states that the sources of drinking water can not be the subject of trade as they ensure a permanent supply of drinking water to public. ${ }^{13}$ Apart from Slovenia, among the EU Member States, the right to drinking water is also protected constitutionally in Slovakia. The Constitution of the Slovak Republic does not regulate the right to drinking water as a basic human right, but stipulates that the flows of underground water, mineral spring waters and waterways are owned by the state, and the state has an obligation on behalf of its citizens and future generations to protect the natural resources and to ban the export of water from the country. ${ }^{14}$ Amending the Constitution in 2015, Art. 4 is complemented with paragraph 2, which introduces a ban of drinking water export, regardless of its means of transport (by use of vehicles or through water supply network).

The 1974 Constitution of SFRY contained a broader definition of the right to a healthy environment that included several areas of environmental protection: “... sitizens have the right and duty to provide conditions for the preservation and development of natural and man-made environmental values, as well as to prevent harmful effects that by pollution of air, soil, water, watercourses and the sea, noise or otherwise threaten these values or endanger human life and health" ${ }^{15}$ Constitutions of the countries in the region also contain the right to a healthy environment. Thus, for example, the Croatian Constitution, in the introductory provisions, before providing guarantees of basic human rights, ranks the environmental protection in line with "the most important values of the constitutional order and the basis for interpreting the Constitution" ${ }^{16}$ It guarantees a general protection to

13 The Constitution of Slovenia, Uradni list RS, no. 75/16 dated 30 November 2016, Art. 70a. Čebulj, J., (So)delovanje strank v splošnem in posebnih upravnih postopkih, Sodelovanje javnosti in stranskih udeležencev v okoljevarstvenih postopkih, 6-7, 2017, p. 989

14 Constitution of Slovak Republic, Ústavného zákona č., no. 161/2014 Z. z., Art. 4

15 Constitution of the SFRY, Službeni list SFRJ, br. 30/1974, Art. 87

16 Constitution of the Republic of Croatia, Narodne novine, no. 56/90, 8/98, 113/00, 28/01, 41/01, 55/01, 76/10, 85/10, 05/14, Art. 3 
environment but also the special protection of the sea, sea coast, islands, water, air and other natural resources, land, forests, flora and fauna, as well as other segments of nature of environmental significance. ${ }^{17}$

The use and disposal of water do not enjoy special legal protection in the Constitution of Serbia. In the Water Act, water is defined as a natural resource owned by the Republic of Serbia, and it prescribes limitations, allowing the right of use of public good and the right of lease of water land. ${ }^{18}$ The water bodies and wells that serve as regional, not local, drinking water supply are considered goods of general interest. ${ }^{19}$ The right to a special use of water, in accordance with the mentioned Law, may be acquired with a water permit or, if it comes to a special use under concession, in accordance with the contract governing the concession. ${ }^{20}$ The question then arises whether current law provides the possibility that, under certain circumstances, further use of drinking water, entrusted with the water permit or concession contract, is limited or excluded. If the water is not used rationally and economically, or if the use of water results in a water shortage, the relevant ministry and the competent authority of the autonomous province can limit the right to the special use of water, but only temporarily. ${ }^{21}$ According to the Law on Public Property, "water, water streams and their resources, mineral resources, groundwater resources, geothermal and other geological resources and reserves of mineral resources" are defined as the natural resources owned by the Republic of Serbia, where concessions or right of use may be granted. ${ }^{22}$

\section{WATER AS A LEGAL PERSON IN COMPARATIVE LAW}

One of the means to achieve a better protection of water quality can be found in comparative law. In November 2016, the Constitutional Court of Columbia reached a decision to declare that the Atrato River basin, exposed to mining that significantly jeopardized nature and local community, has a right to 'protection,

Constitution of the Republic of Croatia, Art. 70 and Art. 52

Water Act, Official Gazette of RS, no. 30/10, 93/12, 101/16, Art. 5

Water Act, Art. 76

Water Act, Art. 68, para. 2

Water Act, Art. 69

Law on Public Property, Official Gazette of RS, no. 72/11, 88/13, 105/14, 104/16-dr. Law 108/16 and Art. 9. Article 8 of that law failed to indicate the specific nature of the regime of water lands. In Art. 8 it is stated that the legal regime of construction land, agricultural land, forests and forest land in public ownership shall be regulated by a special law. Draft Law on Amendments to the Law on Public Ownership of these legal regimes adds the one refering to water land 
conservation, maintenance and restoration'. ${ }^{23}$ The same formulation was argued by the Supreme Court of India, declaring Ganges and Yamuna rivers and their ecosystems as a legal person and ordered the government to establish a management board to represent their interests. ${ }^{24}$ The New Zealand Parliamentary Council set into account the Whanganui River Claims Settlement Bill as a legal framework, which recognizes Whanganui River as 'a legal person with all the rights, powers, duties and liabilities of a legal person'. ${ }^{25}$ In order to 'act and speak on behalf of the Whanganui River and protect its health and well-being' a special procedure for guardians election is provided. ${ }^{26}$ Following that, in its decision the Supreme Court of Colombia recognized the Amazon River ecosystem 'as an entity, subject of rights, and beneficiary of the protection, conservation, maintenance and restoration'. ${ }^{27}$ The case was initiated on the occasion of a lawsuit filed by 25 people aged 7 to 25 , against the Government of Colombia, ministries and authorities of local government, stating that these bodies violate their right to a healthy environment, life and health by failing to control deforestation in the Amazon region, contributing to environmental degradation and climate change. The Supreme Court of Colombia ordered the respondent authorities to include 'plaintiffs, affected communities, and the interested population in general' in the preparation of policies aimed at fighting deforestation and adverse impact of climate change. ${ }^{28}$ The question opens as to how such protection can be achieved, ie. which legal mechanisms would allow the nature to be considered an entity in possession of legally enforceable rights. ${ }^{29}$ In the decision of the Supreme Court of Colombia, the solution was the establishment of 'Intergenerational Pact for the Life of the Colombian Amazon', in whose work plaintiffs, affected communities and scientific groups play an active

23 República de Colombia, Corte Constitucional, T-622 de 2016, Referencia: T-5.016.242, p. 153, par. 10.2, [https://redjusticiaambientalcolombia.files.wordpress.com/2017/05/sentencia-t-622-de-2016rio-atrato.pdf] Accessed 24.03.2019

24 O'Donnell, E.L., At the intersection of the sacred and the legal: rights for nature in Uttarakhand, India, Journal of Environmental Law, Vol. 30, No. 1, 2017, pp.135-144; Kauffman, C.; Martin, P., When Rivers Have Rights: Case Comparisons of New Zealand, Colombia, and India, in: International Studies Association Annual Conference, 2017

25 The New Zealand Parliamentary Counsel Office, 2016, Art. 14 (1). Rodgers, C., A new approach to protecting ecosystems: The Te Awa Tupua (Whanganui River Claims Settlement) Act 2017, Environmental Law Review, Vol. 19, No. 4, 2017, pp. 266-279

26 The New Zealand Parliamentary Counsel Office, 2016, Art. 19. Studley, J.; Bleisch, W.V., Juristic personhood for sacred natural sites: A potential means for protecting nature, PARKS, Vol. 24, 2018, p. 81

27 República de Colombia, Corte Suprema de Justicia, Sala de Casación Civil, Luis Armando Tolosa Villabona, STC4360-2018, Redicación no. 11001-22-03-000-2018-00319-01, p. 45, par. 14, [http://www. cortesuprema.gov.co/corte/wp-content/uploads/2018/04/STC4360-2018-2018-00319-011.pdf] Accessed 06.04.2019

28 Ibid., para. 48

29 Boyd, D.R., The rights of nature: a legal revolution that could save the world, ECW Press, 2017 
role in order to represent the interest of the Amazon River ecosystem that is the subject of rights. ${ }^{30}$

\section{THE CRITERIA FOR WEIGHING UP AN OVERRIDING INTEREST IN CASES DEALING WITH THE INTEREST OF PROTECTING AND PRESERVING WATER QUALITY AND THE INTEREST OF OBTAINING ENERGY FROM RENEWABLE SOURCES IN CJEU PRACTICE}

The approach that natural objects should be given the legal personhood is not a new one. It was used in early 70's, when professor Stone argued that judges could be more sensitive to degradation and disappearance of water, air, soil and other values of nature if one could speak on behalf of nature. ${ }^{31}$ Analysed examples argument that one of the approaches to protect nature is to establish natural resources as a legal minor and to establish certain representative bodies (including environmental groups, affected communities, interested population, scientists) with strong responsibilities to be guardians. The scholars opting for that approach believe that legal framework should provide tools of collective responsibility. ${ }^{32}$ Recognized as a subject of law, water or some other natural object is not considered as private good or common resource, but as a person under the law. The most important issue related to the concept that 'other-than-human' persons can be recognized as legal subjects is who will be recognized as competent and/or interested to speak on behalf of it.

Bearing in mind the obstacles of the first approach, EU focused its water law and protection policy to the issue of criteria that should be used in the proportionality test where an interest of water is balanced with other interests of environmental

30 Bryner, N., Colombian Supreme Court Recognizes Rights of the Amazon River Ecosystem, 20 April 2018, [https://www.iucn.org/news/world-commission-environmental-law/201804/colombian-supreme-court-recognizes-rights-amazon-river-ecosystem] Accessed 08.04.2019

31 Stone, C.D., Should Trees Have Standing--Toward Legal Rights for Natural Objects, S. CAl. 1. rev., Vol. 45, 1972, p. 450; Stone, C.D., Should Trees Have Standing Revisited: How Far Will Law and Morals Reach--A Pluralist Perspective, S. Cal. L. Rev., Vol. 59, 1985, p. 1; Grear, A., Should trees have standing? 40 years on, Edward Elgar, 2012; Mendelson III, J., Should Animals Have Standing: A Review of Standing under the Animal Welfare Act, BC Envtl. Aff. L. Rev., Vol. 24, 1996, p.795; Varner, G.E., Do species have standing?, Environmental Ethics, Vol. 9, No. 1, 1987, pp. 57-72; Goldberg, D.M.; Badua, T., Do People Have Standing-Indigenous Peoples, Global Warming, and Human Rights, Barry L. Rev., Vol. 11, 2008, p.59; Cullinan, C., Do humans have standing to deny trees rights, Barry L. Rev., Vol. 11, 2008, p. 11

32 Iorns Magallanes, C.J., From Rights to Responsibilities using Legal Personhood and Guardianship for Rivers, in: Martin, B.; Te Aho, L.; Humphries-Kil, M. (eds.) ResponsAbility: Law and Governance for Living Well with the Earth, Routledge, London \& New York, 2018, pp.216-239; Maloney, M., Environmental law: Changing the legal status of nature: Recent developments and future possibilities, LSJ: Law Society of NSW Journal, Vol. 49, 2018, p. 78 
protection, ${ }^{33}$ in majority of cases with the use of renewable energy sources. The precondition for balanced measurement is to find the legal framework that would allow public concerned and interested public to take part in that process.

In order to find the criteria that must be taken into account in order to properly assess the various interests that aim at protecting the environment, we shall analyse the practice of CJEU.

The more precise criteria are found in the CJEU practice, in the case regarding the complaint of the European Commission to CJEU arguing that development of a small hydropower project violated the obligations of Austria arising from Directive 2000/60/EC on establishing a framework for EU action in the field of water policy. ${ }^{34}$ The case follows the factual sequence of events that started with a decision of the governor of Styria in Austria to authorise the construction of hydropower plant on the river Schwartz Sulm. One of the side effects of hydropower plant's activity was the deterioration of quality of surface river water, from the state assessed as "very good", to the state asessed as "good", prompting the Commission to send a letter of reminder to Austria, since a high quality surface water has to be considered the public interest. The response stated that the decision to deviate from the prohibition of deterioration of surface water quality was justified by the existence of public interest to use renewable energy sources such as hydropower, which is in this case considered to be an overriding interest. After several cycles of questions and replies, the Commission filed a lawsuit to CJEU. The CJEU noted that constructing a hydropower plant may be an overriding interest, but it established a basis for balancing the expected benefits of the renewable energy projects and the resulting deterioration of the environment. It is noted that national authorities are entitled to find whether the project would give rise to the benefits for the sustainable environment, whether the operator took all necessary measures to mitigate an adverse impact of that project on the environment, whether there is a possibility to achieve the objectives pursued by that project by another project which would have been a "significantly better environmental option", taking into account the technical feasibility or disproportionate costs. ${ }^{35}$ Further, they refer to the methodology that decision-makers should follow in weighing up the overriding interest between protection of water quality and producing energy in small hydropower plants. Arguing that the interests were duly balanced, the CJEU stated that the governor of Styria had not abstractly refered to the overriding public interest of production of energy from renewable sources, but used

\footnotetext{
33 Bakker, K., The "commons" versus the "commodity": Alter-globalization, anti-privatization and the human right to water in the global south, Antipode, Vol. 39, No. 3, 2007, pp. 430-455

34 European Commission v. Republic of Austria, C-346/14, [2016] ECLI:EU:C:2016:322

35 Ibid., pars. 69 and 74
} 
as the basis a scientific analysis of the adverse impact on the state of surface water, the fact that the river has a high environmental quality, as well as the project benefits relating to the production of energy from small hydropower plants. The methodology should be such as to observe the overall environmental impact of the project, as well as the direct and indirect impact on the objectives of Directive 2000/60. ${ }^{36}$

The implementation inspection of these criteria can be carried out by independent bodies, such as the Green Ombudsman, as well as the interested public, as parties to the proceedings. The law of the EU Member States does not prescribe environmental impact assessment (EIA) for small hydroelectric power plants, which raises the question of whether the interested public has the right to take part in the process of deciding on a small hydroelectric power plant when it is not subject to EIA, and whether it is entitled to appeal or file an administrative action due to violation of prohibition on deterioration of the status of all bodies of surface water, in the sense of Article 4 (1) of Water Framework Directive. ${ }^{37}$ In the case Protect Natur- ${ }^{38}$ CJEU stated positions that can be applied to Member States whose rules of administrative procedure and administrative dispute associate the right to file a complaint or lawsuit to a strict impairment of rights doctrine. In the case in question, the company Aichelberglifte Karlstein GmbH requested permission to use river water for the purpose of making artificial snow for a ski resort in accordance with the Austrian Water Act. ${ }^{39}$ According to this law, the environmental organization Protect Natur-, Arten-, und Landschaftsschutz did not have the right to challenge such a permit due to a significant negative impact on water quality, bearing

\footnotetext{
$36 \quad$ Ibid., para. 77 and 80
}

37 In the case of Serbia, the question is whether the interested public may be a party to the proceedings, outside the EIA, if, for example, a parcel of land on which a small hydropower plant is to be build, deviates from the planning document. This is the case especially bearing in mind that at the end of 2018 the Law on planning and construction was amended with Art. 2 para. 26 considering the derivation pipeline as a line infrastructural facility. A new Art. 2 para. 26b) was introduced, which determines the underground parts of the infrastructure as a special type of underground infrastructure facilities, whose construction on agricultural and forest land, as well as on construction land used for agricultural purposes, does not violate land use on the surface of the existing application and issuance of location conditions for construction of these objects can not be conditioned with the existence, or with a sufficient level of development of planning documents for the area that includes the parcels on which construction is planned; Article 2 para. 44 was also introduced, which defines that the electricity facilities are those used for the production, transformation, distribution and transmission of electricity. This is important because the new Art. 69 introduces the possibility that for purpose of construction or placement of objects from the Article 2, points 26), 26b) and 44) of this law, of electronic communications facilities or networks and devices, a building parcel can be formed which deviates from the surface or the positions envisaged in the planning document for that zone

38 Protect Natur-, Arten- und Landschaftsschutz Umweltorganisation v Bezirkshauptmannschaft Gmünd, C-664/15, [2017] ECLI:EU:C:2017:987

39 Wasserrechtsgesetz 1959 - WRG. 1959. StF: BGBl. Nr. 215/1959 (WV) 
in mind that EIA is not mandatory for the described project and that environmental non-governmental organizations according to Water Act have a right to appeal and file a complaint only if an impairment of rights was established in that case. It means that environmental organizations do not have standing outside the EIA. But, the most important argument provided by the Administrative court was that Protect Natur- lost its party status, as it failed to bring the action in administrative procedure on time..$^{40}$ Linking the obligation to protect the quality of water as a common interest, CJEU concluded that recognized environmental organizations must be able to challenge a decision that might violate WFD (Art. 4). Provisions of WFD oblige Member States to support the active participation of interested parties meaning environmental organizations that may provide important arguments of common interest in such procedures. Those arguments led to significant changes of Austrian EIA, which was amended in October 2018. A new rule states that an environmental organization may have a standing and challenge a decision in an environmental procedure if it has more than 100 members. An even more important change is that an appeal submitted by such an organization will not have a priori suspensive effect, contrary to general rule applying to appeals in Austrian administrative procedures and administrative disputes. ${ }^{41}$ This effect may be recognized by the administrative authority that that might decide on suspensive if a 'disproportionate environmental risk' is to be expected.

What this shows is that the EU has a unique approach toward the protection of water that is based on EIA and weighing up different interests of environmental protection. The right that guarantees the legality of procedure is participation, that would provide public concerned and interested public with a right to participate, but also to a right to a collective redress that will be explained in the next part.

\section{THE APPLICATION OF THE MODEL OF BALANCING THE INTEREST IN ENERGY PRODUCTION FROM RENEWABLE SOURCES AND THE INTEREST OF PROTECTING AND MAINTAINING THE QUALITY AND QUANTITY OF WATER IN PRACTICE OF SERBIA}

In Serbian law, EIA is not required when it comes to construction of small hydropower plants. Thus, for example, according to the matrix developed in the Energy

40 Comparing the circumstances with Kafka's Before the Law, Advocate General Sharpston stressed that loosing standing in this case would mean that Protect Natur- should be punished 'for not having done what the national law appears to preclude it from doing', Opinion of Advocate General Sharston delivered on 12 October 2017 on Case C-664/15, para. 120

${ }_{41}$ Access to Justice in Austria: One step forward, two steps back, [https://www.clientearth.org/access-tojustice-in-austria-one-step-forward-two-steps-back/] 05.04.2019 
Law, for the hydropower facilities with capacity up to $1 \mathrm{MW}$ it is not necessary to carry out an EIA. For these objects it is not even necessary to initiate the procedure for issuing energy permits. If a small hydropower plant is planned to produce energy of capacity of over 2 MW, EIA may be required, but is not obligatory, giving the competent administrative authority the discretion to decide on implementation of EIA. ${ }^{42}$ It is mandatory for hydroenergy projects with a capacity exceeding $50 \mathrm{MW}$. The energy permit is an act issued by the competent administrative authority at the request of an authorized entity for the construction of facilities for electricity production capacity of $1 \mathrm{MW}$ and higher. ${ }^{43}$ If the request was filed for the construction of power plants which use water power to generate electricity to power up to $1 \mathrm{MW}$, the competent authority is not obliged to issue a decision, but only a consent. ${ }^{44}$

By ratifying the Treaty on establishing the Energy Community, Serbia assumed the obligations under Directive 2009/28/EC, which, inter alia, deals with the promotion of electricity produced from renewable energy sources. ${ }^{45}$ In this way a system of subsidies on electricity production from renewable energy sources was established to increase the use of renewable energy sources. Introducing incentive fixed purchase price ('feed-in' tariffs), with the period of guaranteed electricity takeover of 12 years, has led to significant interest in the development of small hydropower facilities $(<10 \mathrm{MW})$, increased the number of locations where there is interest to construct small hydropower plants, and there is a growing number of buildings. The Strategy on Water Management of Serbia reads that "the emergence of a large number of investors interested in investing in small hydropower plants in recent years, and in the transition period where appropriate standards were only just established, a considerable pressure was put on some aspects of environmental protection, and there were also cases of endangering other water users (...) the former work of hydropower facilities primarily fulfilled the needs and requirements of the electric power system of Serbia, not taking into account sufficiently the water regime in waterways..." ${ }^{46}$

42 Decree on establishing the list of objects for which impact assessment is mandatory and the list of projects that may require environmental impact assessment, List II, "Official Gazette of RS", No. 114/08

43 Law on Energy, “Official Gazette of RS”, No. 145/14, 95/2018, Art. 30

44 Drenovak-Ivanovic, M., On current issues regarding energy permit and assessment of impact of hydropower premises in the environmental law in Serbia, Split Faculty of Law Journal, Vol. 51, 2014

45 Law on ratification of the Treaty on establishing the Energy Community between the European Community and the Republic of Albania, Republic of Bulgaria, Bosnia and Herzegovina, Republic of Croatia, the Former Yugoslav Republic of Macedonia, Republic of Montenegro, Romania, Republic of Serbia and the United Nations Interim Mission in Kosovo in accordance with the Resolution 1244 of the United Nations Security Council, “Official Gazette of RS”, No. 62/06

46 Water Management Strategy, "Official Gazette of RS”, No. 3/17 (n) 55 
There is an illustrative example in the case in which the approval was granted for the EIA study for the construction project for small hydropower plants in the river valley under a special regime of protection at the Stara Planina Nature Park. ${ }^{47}$ This is the largest fish hatchery in the area and a physically protected biotope with a large number of rare and protected species of birds (including the dipper as a strictly protected species), mammals, reptiles, amphibians (including strictly protected species of creyfish Austropotamobius torrentium) and fish (including protected species of trout Salmo trutta and barbell Barbus Balcanicus). ${ }^{48}$ Nevertheless, none of these species was mentioned in the EIA study, while the possible project impact, nor the Report on the Professional Surveillance of the Institute for Nature Protection of Serbia, which confirms the presence of these protected and strictly protected species, were not taken into consideration. ${ }^{49}$ As a measure of nature protection, this Report proposed "a permanent ban of all activities that could lead to violation of existing habitat conditions: river restructuring, water capture, etc." 50 On this occasion, the Law on Nature Protection (Article 9), which establishes the obligation for the nature protection conditions issued by the Institute for $\mathrm{Na}$ ture Conservation to form an integral part of the EIA study, was also neglected. However, this case also shows an increase of the role of local community in environmental protection. Namely, after the decision of the Ministry, the association of local communities and citizens of the disputed area made a decision to ban the construction of small hydropower plants in the area of the Nature Park and notified the Ministry thereof, pointing to omissions and neglected documents in the process of granting approval to the Study. Although the same reasons were emphasized in the process of granting approval to the Study, the Ministry identified the circumstances as a finding of new facts and, in accordance with the General Administrative Procedure Act ${ }^{51}$, adopted a decision on the repetition of the procedure for determining the nature protection conditions and the repetition of the approval procedure on the Study. ${ }^{52}$ This decision was annulled by the Administrative court who found that administrative procedure could be repeated only if the Institute for Nature Conservation issued different conditions or otherwise

47 Decision of the Ministry of Environmental Protection no. 353-02-1374 / 2017-16 of 18 June 2017

48 According to the Code of Regulations on the Declaration and Protection of Strictly Protected and Protected Wild Species of Plants, Animals and Fungi (“Official Gazette of RS”, No. 5/10, 98/16), their destruction, use and undertaking of activities that could endanger these species and their habitats is prohibited. In addition, the fact was disregarded that according to the Law on Sustainable Use of Fish Fund ("Official Gazette of RS", No. 128/14), the said area enjoys a special protected status

49 Report on the Professional Surveillance of the Institute for Nature Protection of Serbia of 10-12 July 2017 no. 026-3083 / 2 of 26 December 2017

50 Ibid.

51 General Administrative Procedure Act (“Official Gazette of RS”, No. 18/16), Art. 176 para. 1

52 Decision of the Ministry of Environmental Protection no. 353-02-1374 / 2017-16 of 23 January 2018 
decided on the conditions and measures necessary for the natural protection..$^{53}$ It is also supported by the fact that in the reasoning of the disputed decision the Ministry stated that it would be necessary to obtain a new decision on the conditions of nature protection from the Institute for Nature Conservation as there are new facts provided by the supervision due to which the validity of the decision on EIA Study is arguable. After the Ministry had filed a lawsuit, the Supreme Court of Cassation found that the request for review of the challenged verdict was established and that the request was upheld. Consequently, the Supreme Court of Cassation reversed the ruling of the Administrative Court and dismissed the lawsuit. This Court stated that the decision of the Institute on the conditions of nature protection is one of the acts submitted in the procedure for assessing the environmental impact of the project in the protected area. The EIA study can not be completed without that decision. The Supreme Court of Cassation decided that the decision of the Administrative Court was unacceptable. ${ }^{54}$

What this shows is that Serbia implemented an EU model which uses EIA and balancing different interests of environmental protection as the basis for protection of water. The European Commission issued a Recommendation on Collective redress that should root collective redress allowing persons and groups affected by the same violation of environmental rights access to justice using the right to appeal or take procedure under the court in order to seek injunctive or compensatory relief. ${ }^{55}$ In 2018, EU reported that the Recommendation did not have significant influence, as only five Member States introduced legislation that recognize proposed measures. ${ }^{56}$ One of the examples where the idea of collective redress in environmental protection is transposed is the new Serbian General Administrative Procedure Act (2016). It entrusted the right of participation in decision-making in an administrative procedure to 'representatives of collective interests'. ${ }^{57}$ After those changes, legal standing is granted to legal persons and associations of citizens dealing with protection, improvement and promotion of environmental protection, as protectors of collective and broader public interests, assuming that they have a legal interest for participating in procedures concerning environmental protection.

\footnotetext{
53 Judgment of the Administrative Court, 9 U. 2424/18 of 17 April 2018

54 Judgment of the Supreme Court of Cassation, Uzp 189/2018 of 26 September 2018

55 Commission Recommendation of 11 June 2013 on common principles for injunctive and compensatory collective redress mechanisms in the Member States concerning violations of rights granted under Union Law, OJ L 201, 26.7.2013, pp. 60-65

56 Friel, A., Commission report highlights lack of EU commitment towards ensuring collective redress for environmental protection, [https://www.clientearth.org/commission-report-highlights-lack-eu-commitment-towards-ensuring-collective-redress-environmental-protection/] Accessed 07.03.2018

57 General Administrative Procedure Act, Official Gazette of the Republic of Serbia, No. 18/2016, Art. 44 , para. 3
} 


\section{CONCLUSION}

Conducted analyses show that the right to water can be protected as a right to a specific unit of water (eg. river, all its tributaries and ecosystems), or as a right that protects a certain value (eg. the quantity or quality of water). The first approach leads to the development of the right to water, leading to further elaboration of a model that perceives water as a subject of rights giving it a legal person status. The second approach leads to the development of the right to water that introduces the possibility of protecting water as a value for itself based on criteria that start from weighing up different interests of environmental protection. In both cases we find the need to provide a group of people with the opportunity, in the name of a protected interest, to have a right to legal protection, in the first model, or to take part in weighing up the overriding interest in the second model.

In the jurisprudence of the CJEU we find the criteria which, in matters of importance for the further development of small hydropower plants, would guarantee the implementation of the second model, taking into account the elements of the first model that provides protection of the right to water as a special value. On a case-by-case base, different interests have to be balanced: whether the project would give rise to the sustainable benefits for the environment; how an adverse impact of that project on the environment is mitigated; is there another project which would have been a "significantly better environmental option". In addition to the above criteria, weighing up the interests should be accompanied by a process in which various groups that have an interest, including those who speak in the name of water as a special value, are able to engage and direct the adoption of higher quality decisions. The development of models of collective redress contributes to such involvement. Good balancing of interests and finding the one that overrides may indicate that in some cases the interest of protection of (the quality of) water is overriding, while in other cases the overriding interest is the one that can only be achieved through construction of small hydropower plants, by implementing the procedure in accord with the described methodology.

\section{REFERENCES}

\section{BOOKS AND ARTICLES}

1. Bakker, K., The "commons" versus the "commodity": Alter-globalization, anti-privatization and the human right to water in the global south, Antipode, Vol. 39, No. 3, 2007, pp. 430-455

2. Bluemel, E.B., The implications of formulating a human right to water, Ecology LQ, Vol. 31, 2004, p. 957

3. Boyd, D.R., The rights of nature: a legal revolution that could save the world, ECW Press, 2017 
4. Bullinger, M., Französischer service public und deutsche Daseinsvorsorge, Juristenzeitung, 2003, pp.597-604

5. Čebulj, J., (So)delovanje strank v splošnem in posebnih upravnih postopkih, Sodelovanje javnosti in stranskih udeležencev v okoljevarstvenih postopkih, Vol. 6-7, 2017, p. 989

6. Clausen, S.; Kramer, D.R., Bericht über die 32. Fachtagung der Gesellschaft für Umweltrecht, Natur und Recht, Vol. 31, No. 2, 2009, pp. 104-107

7. Cullinan, C., Do humans have standing to deny trees rights, Barry L. Rev., Vol. 11, 2008, p. 11

8. Daly, E., Environmental Constitutionalism in Defense of Nature, Wake Forest L. Rev., Vol. 53, 2018, p. 667

9. Drenovak-Ivanovic, M., On current issues regarding energy permit and assessment of impact of hydropower premises in the environmental law in Serbia, Split Faculty of Law Journal, Vol. 51,2014

10. Edward Elgar; Mendelson III, J., Should Animals Have Standing: A Review of Standing under the Animal Welfare Act, BC Envtl. Aff. L. Rev., Vol. 24, 1996, p. 795

11. Gleick, P.H., The human right to water, Water policy, Vol. 1, No. 5, 1998, pp. 487-503

12. Goldberg, D.M.; Badua, T., Do People Have Standing-Indigenous Peoples, Global Warming, and Human Rights, Barry L. Rev., Vol. 11, 2008, p. 59

13. Gordon, G.J., Environmental Personhood, Colum. J. Envtl. L., Vol. 43, 2018, p. 49

14. Grear, A., Should trees have standing? 40 years on, 2012,

15. Iorns Magallanes, C.J., From Rights to Responsibilities using Legal Personhood and Guardianship for Rivers, in: Martin, B.; Te Aho, L.; Humphries-Kil, M. (eds.), ResponsAbility: Law and Governance for Living Well with the Earth, Routledge, London \& New York, 2018, pp.216-239

16. Kauffman, C.; Martin, P., When Rivers Have Rights: Case Comparisons of New Zealand, Colombia, and India, in: International Studies Association Annual Conference, 2017

17. Lillo, A., Is Water Simply a Flow: Exploring an Alternative Mindset for Recognizing Water as a Legal Person, Vt. J. Envtl. L., Vol. 19, 2018, p. 164

18. Maloney, M., Environmental law: Changing the legal status of nature: Recent developments and future possibilities, LSJ: Law Society of NSW Journal, Vol. 49, 2018, p. 78

19. McCaffrey, S.C., A human right to water: Domestic and international implications, Geo. Int'l Envtl. L. Rev., Vol. 5, 1992, p. 1

20. O'Donnell, E.L., At the intersection of the sacred and the legal: rights for nature in Uttarakhand, India, Journal of Environmental Law, Vol. 30, No. 1, 2017, pp.135-144

21. Rodgers, C., A new approach to protecting ecosystems: The Te Awa Tupua (Whanganui River Claims Settlement) Act 2017, Environmental Law Review, Vol. 19, No. 4, 2017, pp. 266-279

22. Rodi, M., Public environmental law in Germany, Comparative Environmental Law in Europe. An Introduction to Public Environmental Law in EU Member States. The Hague: Kluwer, 2002, pp. 199-245

23. Stone, C.D., Should Trees Have Standing Revisited: How Far Will Law and Morals Reach--A Pluralist Perspective, S. Cal. L. Rev., Vol. 59, 1985, p. 1

24. Stone, C.D., Should Trees Have Standing--Toward Legal Rights for Natural Objects, S. CAl. I. rev., Vol. 45, 1972, p.450 
25. Studley, J.; Bleisch, W.V., Juristic personhood for sacred natural sites: A potential means for protecting nature, PARKS, Vol. 24, 2018, p. 81

26. Varner, G.E., Do species have standing?, Environmental Ethics, Vol. 9, No. 1, 1987, pp. 57-72

27. Zobavnik, I., Pitna voda, Državni zbor, 2015, p. 24

\section{EU LAW}

1. Commission Recommendation of 11 June 2013 on common principles for injunctive and compensatory collective redress mechanisms in the Member States concerning violations of rights granted under Union Law, OJ L 201, 26.7.2013, pp. 60-65

2. European Commission, Guidance on the requirements for hydro power in relation to Natura 2000, European Commission, 2018, p. 19

3. European Commission v. Republic of Austria, C-346/14, [2016] ECLI:EU:C:2016:322

4. Protect Natur-, Arten- und Landschaftsschutz Umweltorganisation v Bezirkshauptmannschaft Gmünd, C-664/15, [2017] ECLI:EU:C:2017:987

5. Opinion of Advocate General Sharston delivered on 12 October 2017 on Case C-664/15

\section{WEBSITE REFERENCES}

1. Access to Justice in Austria: One step forward, two steps back, [https://www.clientearth.org/ access-to-justice-in-austria-one-step-forward-two-steps-back/] Accessed 05.04.2019

2. Bryner, N., Colombian Supreme Court Recognizes Rights of the Amazon River Ecosystem, 20 April 2018, [https://www.iucn.org/news/world-commission-environmental-law/201804/ colombian-supreme-court-recognizes-rights-amazon-river-ecosystem] Accessed 08.04.2019

3. Convention on the Protection and Use of Transboundary Watercourses and International Lakes, Helsinki, 17 March 1992, [https://www.unece.org/env/water/] Accessed 31.03.2019

4. Friel, A., Commission report highlights lack of EU commitment towards ensuring collective redress for environmental protection, [https://www.clientearth.org/commission-reporthighlights-lack-eu-commitment-towards-ensuring-collective-redress-environmental-protection/] Accessed 07.03.2018

5. Spain plans switch to $100 \%$ renewable electricity by 2050, [https://www.theguardian.com/environment/2018/nov/13/spain-plans-switch-100-renewable-electricity-2050] Accessed 13.11.2018

6. República de Colombia, Corte Constitucional, T-622 de 2016, Referencia: T-5.016.242, p. 153, par. 10.2, [https://redjusticiaambientalcolombia.files.wordpress.com/2017/05/sentencia-t-622-de-2016-rio-atrato.pdf] Accessed 24.03.2019

7. República de Colombia, Corte Suprema de Justicia, Sala de Casación Civil, Luis Armando Tolosa Villabona, STC4360-2018, Redicación no. 11001-22-03-000-2018-00319-01, p. 45, par. 14, [http://www.cortesuprema.gov.co/corte/wp-content/uploads/2018/04/STC43602018-2018-00319-011.pdf] Accessed 06.04.2019

8. Resolution adopted by the General Assembley on 28 July 2010, no. 64/292, The human right to water and sanitation, [https://www.un.org/en/ga/search/view_doc.asp?symbol=A/ RES/64/292] Accessed 06.04.2019 